\title{
THE ENVIRONMENTAL IMPACT OF RADIONUCLIDES FROM SOIL AND CLAY MATERIAL FOUND IN "ZBEGOVI" DEPOSIT IN DONJE CRNILJEVO
}

\author{
UDC 550.378.553.61:631.4(497.11)
}

\author{
Sreten Ilić ${ }^{1}$, Tatjana Golubović ${ }^{2}$, Tatjana Marković ${ }^{1}$, Nataša Pajić ${ }^{1}$ \\ ${ }^{1}$ Military Technical Institute, Belgrade, Serbia \\ ${ }^{2}$ Faculty of Occupational Safety, University of Niš, Serbia
}

\begin{abstract}
The paper presents the results of testing radionuclide content in soil and clay samples on the surface mine "Zbegovi" in Donje Crniljevo, Serbia. The results of the study show that the activity of clay samples and surrounding soil derives mainly from natural radionuclides: ${ }^{232} \mathrm{Th},{ }^{238} \mathrm{U}$ and ${ }^{40} \mathrm{~K}$. The radioactivity of the samples was determined by the gamma spectrometric method using HPGe detector with relative efficiency of 56.2\%. The obtained results show that the tested samples can be used as material for brick and ceramic products, cosmetics as well as the fact that the tested clay deposit does not have a negative impact on humans, plants and animals.
\end{abstract}

Key words: clay, soil, radioactivity, ${ }^{232} \mathrm{Th},{ }^{238} \mathrm{U},{ }^{40} \mathrm{~K}$.

\section{INTRODUCTION}

The exposure to natural radioactivity in the environment is inevitable. Natural radioactivity comes primarily from three natural radioactive parent isotopes: ${ }^{232} \mathrm{Th},{ }^{238} \mathrm{U}$ and ${ }^{235} \mathrm{U}$, as well as ${ }^{40} \mathrm{~K}[1]$. Uranium and radium, as the most important natural radionuclides, appear in lithosphere and hydrosphere in various geological bodies: rocks, ores, soil, and underground and surface waters [2].

As a complex material, the soil contains a mineral (inorganic) and an organic component that largely appear due to decomposition of plant matter. The inorganic or mineral component of soil consists of particles composed of the actions of various abiotic and biotic factors in rocks. Since rocks which are part of the Earth's crust have certain concentration of natural radionuclides, they are expected to be found in the soil originating from decomposition of rocks.

Received March 24, 2018 / Accepted June 1, 2018

Corresponding author: Tatjana Golubović

Faculty of Occupational Safety, University of Niš, Čarnojevića 10A, 18000 Niš, Serbia

E-mail: tatjana.golubovic@znrfak.ni.ac.rs 
Table 1 shows the characteristic values of activity concentrations of ${ }^{40} \mathrm{~K},{ }^{232} \mathrm{Th}$ and ${ }^{235} \mathrm{U}$ in characteristic rocks [1].

Table 1 Characteristic values of activity concentrations of ${ }^{40} \mathrm{~K},{ }^{232} \mathrm{Th}$ and ${ }^{235} \mathrm{U}$ in specific rocks

\begin{tabular}{cccccc}
\hline Radionuclide & Basalt & Syenite & Granite & Limestone & Sandstone \\
\hline${ }^{40} \mathrm{~K}[\mathrm{~Bq} / \mathrm{kg}]$ & 210.00 & 1400.00 & 1290.00 & 89.00 & 370.00 \\
${ }^{232} \mathrm{Th}[\mathrm{Bq} / \mathrm{kg}]$ & 6.50 & 69.20 & 87.50 & 7.00 & 11.00 \\
${ }^{235} \mathrm{U}[\mathrm{Bq} / \mathrm{kg}]$ & 5.30 & 102.00 & 59.70 & 28.00 & 19.00 \\
\hline
\end{tabular}

The distribution of artificial radionuclides in soil is characterized by highly uneven profile depths. In regions with moderate levels of atmospheric precipitates, in the soil of heavier mechanical composition, the greatest part of anthropogenic radionuclides remain in the surface layer of soil (up to $10 \mathrm{~cm}$ depth) over a longer period of time. Medium heavy and heavy natural radionuclides are accumulated here, as well as artificial radionuclides at 5 to $20 \mathrm{~cm}$ depths where they form compounds with organic substances [3]. In lighter and sandy soils, especially in those which, in terms of water regime, can be classified as leachate, a considerable part of radioactive substances migrate to a depth of $40-50 \mathrm{~cm}$ over a 10- to-15-year period; nevertheless, they can reach the groundwater as well as the rivers and the seas [4].

Geochemical processes are characterized by the cyclical movement of chemical elements and isotopes in the living environment. Various natural-occuring radionuclides are present in soil, mainly in very low content. Depending on the geochemical cycles of the elements, local concentration of radionuclides in soil should not exceed the limits that are hazardous to human health.

Apart from ${ }^{232} \mathrm{Th},{ }^{238} \mathrm{U}$ and ${ }^{235} \mathrm{U}$, soil contains about 50 radioactive elements which belong to their series. If the activities of all radioactive elements in one series are in radioactive equilibrium, the activity of each element is equal to the activity of the first element in a series. In case of artificial radioactive elements, ${ }^{137} \mathrm{Cs}$ can usually be found in soil in the amount above the detection threshold of low-frequency detector systems. This isotope with a half-life of 30 years reached the environment to a great extent during a disaster in a nuclear power plant in Chernobyl due to human error. It has been concluded that some of the accidents could have been prevented, or even predicted if human error assessment techniques have been timely applied [5]. Even 32 years after this accident, this isotope can still be found in soil samples.

Clays represent widespread mineral wealth of great industrial significance [6]. In some types of clay, there is high content of ${ }^{232} \mathrm{Th}$ and ${ }^{238} \mathrm{U}$ above the allowed limits prescribed by the legislation [7].

In the process of clay exploitation for construction purposes, it is necessary to perform appropriate examination of the type, quality and quantity of mineral raw materials, as well as the content of radionuclides in clay. Also, clay should also be tested in terms of their use in the pharmaceutical industry, both for outdoor (clay wrap, clay facial masks, hair regenerator) and for internal use (pre-oral use that lasts for several weeks)[8]. It is believed that surface exploitation of clay in Serbia has degraded about 850 ha of land, while less than $20 \%$ has been recultivated. 


\section{GEOMORPHOLOGY OF THE "ZBEGOVI" OPEN PIT, DONJE CRNILJEVO}

In the middle part of the $20^{\text {th }}$ century, economically interesting quantities of ceramic clay deposits were discovered in the western part of the Tamnava tertiary basin (Western Serbia) [9]. The studied deposits of plastic pottery clays are rather small and mainly located in the wider area of the village of Donje Crniljevo. At the moment, these clays constitute the entire raw material inventory of high-quality light brown plastic clay in Serbia.

Clays usually appear at a depth of 2-35 m [9]. The Miocene productive series ends with various sands, gravels and conglomerates. The clays that are found in this basin do not have a certain stratigraphic position but rather appear at different levels of the MioPliocene series, with frequent transition from fatty clays over clayey sands to quartz sands. Lenticular occurrence of clay in diverse levels of the Miocene series can be justified by frequent oscillations of Mio-Pliocene waters, lifting and deepening of the basin bed and the deposition of sediments.

On the basis of mineral, physical, chemical and technological examination of the quality of composite crude ceramic clays from active deposits in Donje Crniljeve [9], following four types of commercial clay were isolated in the sediments of the Jovanovića Brdo, the Bele Vode and the Zbegovi (opened in 2007):

a) red-yellow sandy-gravel clay (brick clay);

b) grey-white poor sandy clay (ceramic and refractory clay);

c) dark coal clays (ceramic clay);

d) interspersed (lamellar), fatty and poor sandy clay (distinguished by the high content of aluminum and iron).

Brick clays are intended for internal use, and the most important is the grey-sandy ceramic clay, which was used for the production of white facade brick. All three types of ceramic clays from the Tamnava tertiary basin can be widely used in non-metal processing industry; therefore, these deposits could greatly contribute to further economic development of this part of Southeast Europe [9].
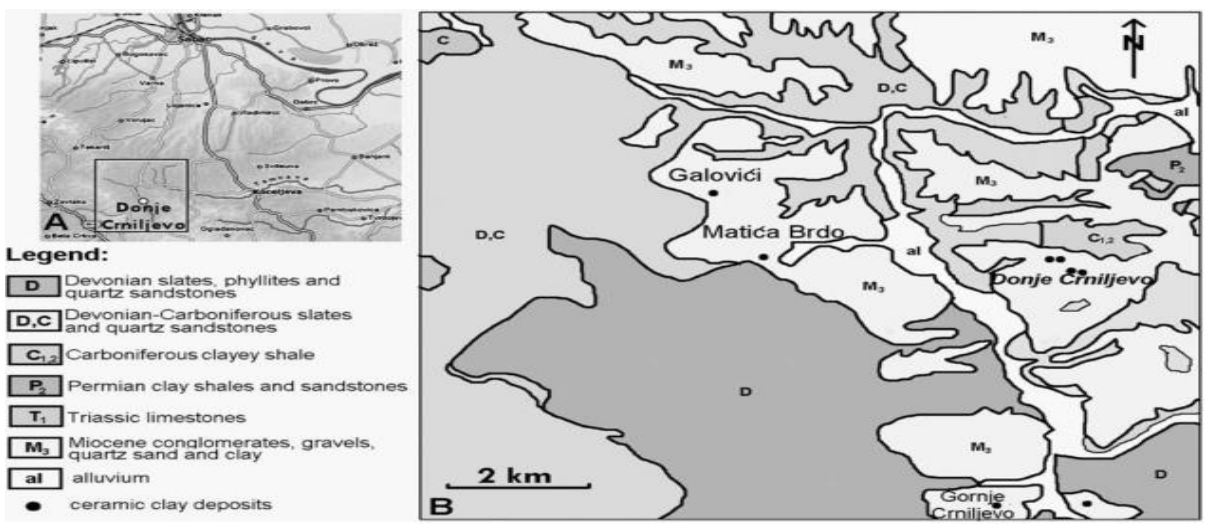

Fig. 1 Location and geological map of the Tamnava tertiary basin [9]

By analyzing the obtained data on the mineralogical composition of the examined ceramic clay deposits in the Tamnava basin, it can be concluded that they differ in the granulometric composition (different proportions of sand, dust and clay fraction) and they contain other substances (quartz, smectite clay, iron minerals, organic matter). 
Examination of chemical composition was performed according to the methods prescribed by JUS V.V.8.070 standard. After the chemical analysis of the sampled material, the chemical composition of the ceramic clay is shown in Table 2 [9].

Table 2 Chemical composition of the ceramic clay raw material (in weight percent, wt $\%$ )

\begin{tabular}{lcccccccc}
\hline Component & $\mathrm{SiO}_{2}$ & $\mathrm{Al}_{2} \mathrm{O}_{3}$ & $\mathrm{Fe}_{2} \mathrm{O}_{3}$ & $\mathrm{TiO}_{2}$ & $\mathrm{CaO}$ & $\mathrm{MgO}$ & $\mathrm{Na}_{2} \mathrm{O}$ & $\mathrm{K}_{2} \mathrm{O}$ \\
\hline Content & 61.87 & 21.63 & 1.17 & 1.01 & 1.05 & 0.46 & 0.07 & 2.05 \\
\hline
\end{tabular}

There are many secondary deposits of uranium ore in Serbia, including the Iverak, in sedimentary formations of pre-neogenous and neogenous age, located at a relatively short distance from the "Zbegovi" deposit [10].

\section{SAMPLing AND MEASUREMENT METHOdOLOGY}

In the vicinity of the open pit "Zbegovi", from a 0.5 hectares meadow, which is located at the hillside above the pit (Figure 2), two soil samples were taken, from a depth of $30 \mathrm{~cm}$ and from a depth of 30-60 cm, respectively (Sample 1 and 2). Soil samples were collected using the IAEA method (International Atomic Energy Agency): Technical Report Series No.295 - Measurement of Radionuclides in Food and the Environment Section 5. Collection and Preparation of Samples-page 27 (5.2.3 Soil) [11]. The next sample was taken from the soil layer at a depth of 10-15 m, i.e. from the mixture of the first layer of clay found in soil (Sample 3). Since the clay layer is not watertight, it is expected that this sample has increased radioactivity due to the accumulation of radionuclides that were vertically moving downward. The next clay sample was collected at a depth of 50 to $70 \mathrm{~m}$ (Sample 4).

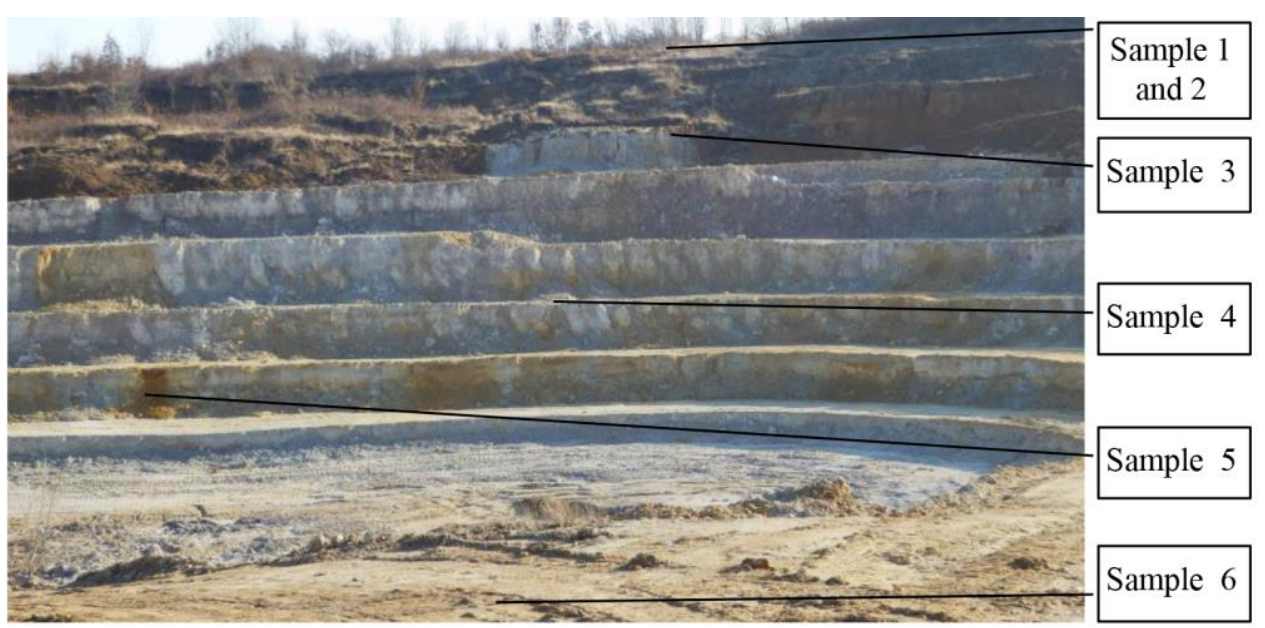

Fig. 2 The location of soil and clay sampling from the open pit "Zbegovi"

The next sample was taken at a $70 \mathrm{~m}$ depth (Sample 5) - a layer of yellow sand that lies between two layers of clay. The final samples were tailings (Sample 6), which are a 
mixture of all types of soil to be found on the open pit "Zbegovi". The samples were collected on February 15, 2017, where the mass of the soil per sample was $2.5-3.5 \mathrm{~kg}$.

The soil samples were dried at $105^{\circ} \mathrm{C}$ to obtain constant mass. Afterwards, all mechanical impurities, mainly parts of the plant material, were removed. The dried soil samples were mechanically ground to a fine powder form $(0.5 \mathrm{~mm})$ and homogenized, and later this kind of material was placed in Marinelli vessels (1000 ml volume, shape of the cylinder, $62 \mathrm{~mm}$ high and $67 \mathrm{~mm}$ in diameter). Subsequently, the measurement vessels were hermetically sealed with paraffin and left for 40 days to achieve radioactive equilibrium between the members of the radioactive series. A typical sample weight was between 1195 and 1580 grams. Gamma spectrometric analysis of samples was performed using standard methods according to ISO 18598 standard [12, 13, 14].

Measurement of radionuclide activity in samples was performed using the high resolution semiconductor HPGe detector produced by "AMETEC-ORTEK" (Figure 3), with the energy resolution (FWHM, full width half maximum), from $1.78 \mathrm{keV}$ to $1332 \mathrm{keV}$ and the relative efficiency of $56.2 \%$.

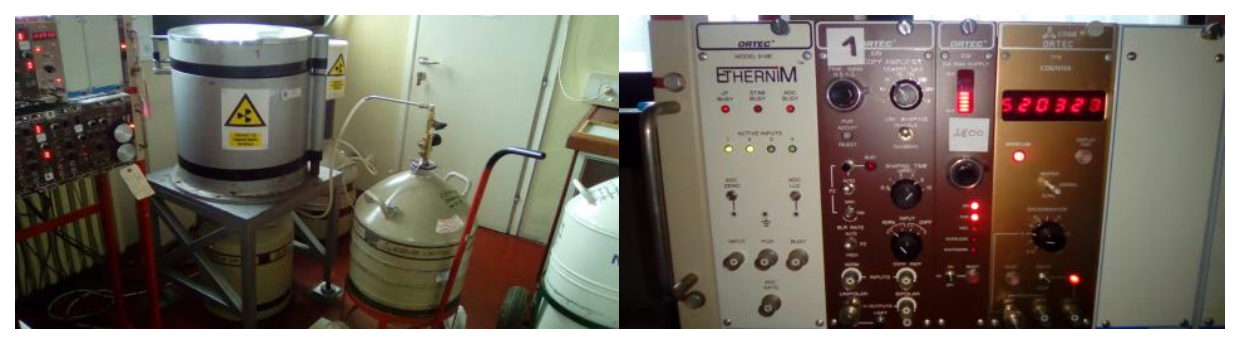

Fig. 3 High-resolution semiconductor HPGe detector "AMETEC-ORTEK" GEM50

The detector is placed in a special low-voltage protective chamber with lead walls $(12 \mathrm{~cm}$ thick) and a copper inner layer (5 mm thick). The typical measurement time of the individual sample was 100,000 seconds. The calibration of the detector was carried out using a radioactive standard in $1000 \mathrm{ml}$ Marinelli vessel, type MBSS, produced by the Inspectorate for ionizing radiation of the Czech metrological institute. Calibration was performed using silicone resin matrix spiked with a series of following radionuclides: ${ }^{241} \mathrm{Am},{ }^{109} \mathrm{Cd},{ }^{59} \mathrm{Co}$, ${ }^{139} \mathrm{Ce},{ }^{133} \mathrm{Ba},{ }^{113} \mathrm{Sn},{ }^{85} \mathrm{Sr},{ }^{137} \mathrm{Cs},{ }^{88} \mathrm{Y},{ }^{54} \mathrm{Mn}$ and ${ }^{60} \mathrm{Co}$. Spectrum analyzes were made based on the gamma lines present using the Gamma Vision software package [15].

\section{RESUlTS AND DISCUSSION}

By measuring samples, natural radionuclides were detected from natural radioactive decay series ${ }^{238} \mathrm{U}\left({ }^{226} \mathrm{Ra},{ }^{214} \mathrm{~Pb},{ }^{214} \mathrm{Bi}\right),{ }^{232} \mathrm{Th}\left({ }^{228} \mathrm{Ac},{ }^{212} \mathrm{~Pb},{ }^{212} \mathrm{Bi}\right.$ and $\left.{ }^{208} \mathrm{Tl}\right)$ as well as and long-lived ${ }^{40} \mathrm{~K}$. Artificial radionuclides were not detected. The activity of ${ }^{232} \mathrm{Th}$ was determined on the basis ${ }^{228} \mathrm{Ac}(911,07 \mathrm{keV}, 968,90 \mathrm{keV}$ and $338,40 \mathrm{keV}),{ }^{208} \mathrm{Tl}(2614,47$ $\mathrm{keV}, 583,14 \mathrm{keV}, 510,72 \mathrm{keV}$ and $860,47 \mathrm{keV}),{ }^{212} \mathrm{~Pb}(238,63 \mathrm{keV})$ and ${ }^{212} \mathrm{Bi}(727,17$ $\mathrm{keV}$ ). The activity of ${ }^{40} \mathrm{~K}$ was observed directly on the basis of its own gamma line at $1460.75 \mathrm{keV}[15]$. 
Table 3 Activity concentrations of radionuclides in soil and clay samples from "Zbegovi" deposit in Donje Crniljevo

\begin{tabular}{llccc}
\hline \multirow{2}{*}{ Sample } & & \multicolumn{3}{c}{ Radionuclide activity $[\mathrm{Bq} / \mathrm{kg}]$} \\
& & ${ }^{40} \mathrm{~K}$ & ${ }^{232} \mathrm{Th}$ & ${ }^{238} \mathrm{U}$ \\
\hline Sample 1 & (0-30 cm soil depth) & $391.4 \pm 20$ & $48.2 \pm 12$ & $181.0 \pm 7.2$ \\
Sample 2 & (30-60 cm soil depth) & $1.9 \pm 0.1$ & $1.70 \pm 0.4$ & $93,9 \pm 3.8$ \\
Sample 3 & (10-15 m soil depth) & $23.7 \pm 1.2$ & $3.2 \pm 0.8$ & $101.9 \pm 4.1$ \\
Sample 4 & (clay at 50-70 m depth) & $24.7 \pm 1.2$ & $7.7 \pm 1.9$ & $98.5 \pm 3.9$ \\
Sample 5 (the layer of yellow sandstone at 70 m depth) & $26.0 \pm 1.3$ & $1.6 \pm 0.4$ & $75.8 \pm 3.4$ \\
Sample 6 (tailings) & $8.7 \pm 0.4$ & $2.5 \pm 0.6$ & $38.7 \pm 1.7$ \\
\hline
\end{tabular}

The values are given as mean $\pm \mathrm{SD}$

Table 3 shows the measured activities of radionuclides detected in all soil samples. From Figure 3, it can be seen that the sample 1 has the highest activity in case of all three characteristic radionuclides found in soil. The increased presence of ${ }^{40} \mathrm{~K}$ in a sample of surface soil $(0-30 \mathrm{~cm})$ could be explained by the effect of longstanding accumulation of potassium from artificial fertilizers used in arable lands (meadow). Also, sample 1 was characterized by the highest activity ${ }^{238} \mathrm{U}$ and ${ }^{232} \mathrm{Th}$; however, their concentration in soil is within the permissible values and they have no negative impact on the environment [16].

Also, a slight accumulation of ${ }^{238} \mathrm{U}$ in soil was noticed at 10 to $15 \mathrm{~m}$ depth, on the first layer of clay which, as a waterproofing layer, prevented vertical migration of the mentioned radionuclide, which consequently resulted in accumulation of material.

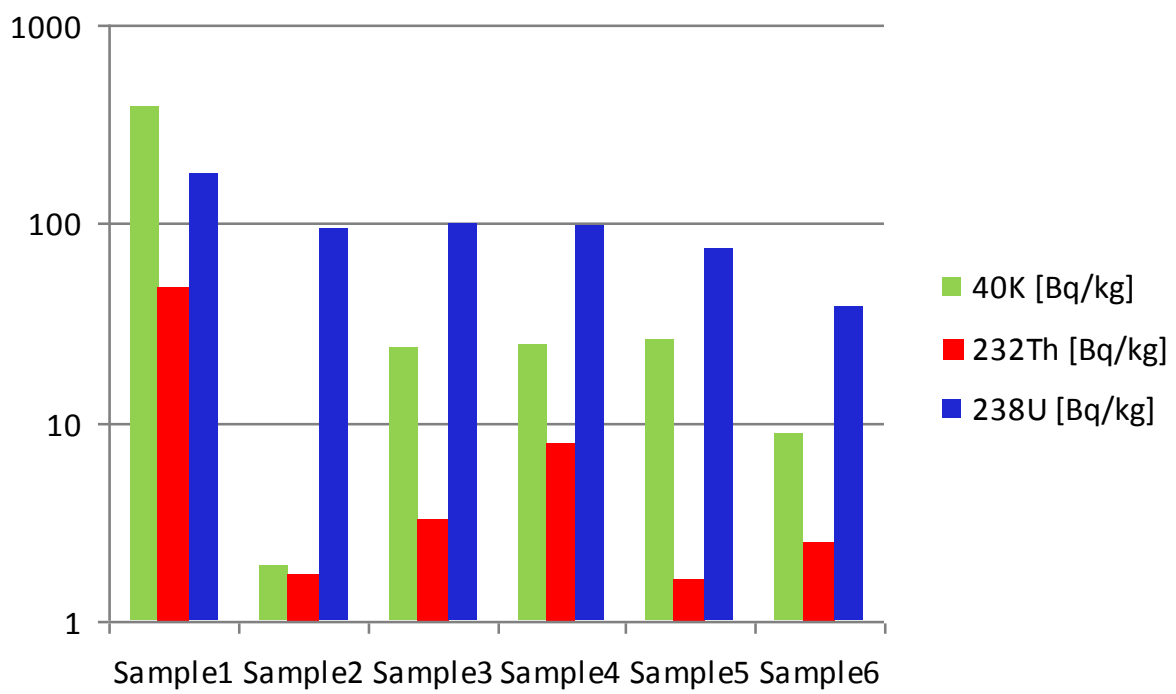

Fig. 4 Activity concentrations of radionuclides in soil and clay material in the open pit "Zbegovi" in Donje Crniljevo 


\section{CONCLUSION}

After a gamma-spectrometric analysis, it can be concluded that the clay samples from the open pit "Zbegovi" in Donje Crniljevo are "technical raw material", which can be used freely for the production of brick and ceramic products, as well as in the pharmaceutical industry. The clay deposit itself has no negative impact on the living environment in terms of increased radioactivity.

\section{REFERENCES}

1. Forkapić, S., Bikit, I., Mrđa, D., Todorović, N., Krmar, M., Slivka, J. and Vesković, M., Ispitivanje sadržaja radionuklida u zemljištu $i$ sadržaja $210 \mathrm{~Pb}$ u lišću novosadskih parkova, http://www.iaea.org/inis/collection/ NCLCollectionStore/Public/39/066/39066547.pdf

2. Dangić, A., Gordanić, V. and Dangić, J., Geohemijski procesi i geohemijske anomalije uranijuma, radijuma $i$ radona u tlu, vodama $i$ vazduhu kao ekološki rizici, Jonizujuća zračenja iz prirode monografija str. 57, ISBN 86-80055-75-1, 1995.

3. Durić, G. and Popović, D., Problemi kontrole radionuklida u životnoj sredini, XIX jugoslovenski simpozijum zaštite od zračenja, Zbornik radova, Golubac, 1997.

4. Janković - Mandić, Lj., Dragović, R., Đorđević, M., Đolić, M., Onjia, A., Dragović, S., Bačić, G., Prostorna varijabilnost ${ }^{137}{ }^{13}$ u zemljištu Beograda (Srbija), Naučni rad, UDK 546.36:539.166, Hemijska industrija, 68 (4) 449-455, 2014.

5. Stojiljković, E., Glišović, S. and Golubović, T., Risk assessment of industrial and environmental monitoring systems - the significance of human reliability analysis $\square$, FACTA UNIVERSITATIS Series: Working and Living Environmental Protection Vol.11, No 2, pp. 145 - 152, 2014.

6. Đukić, A. B., Adsorpcija jona teških metala iz vodenih rastvora na kompozitu montmorionit/kaolinit glina - titan(IV)-oksid, Doktorska disertacija, Fakultet za fizičku hemiju Univerziteta u Beogradu, 2016.

7. Riekstina, D., Berzins, J., Krasta, T., Svinka, R., Skrypnik, O., Natural radioactivity in clay and building materials used in Latvia, LATVIAN JOURNAL OF PHYSICS AND TECHNICAL SCIENCES 2015.

8. Todorović, D., Popović, D. and G. Đurić, Prirodni radionuklidi u glinama koje se koriste u farmaceutskoj industriji, XIX jugoslovenski simpozijum zaštite od zračenja, Zbornik radova, Golubac, 1997.

9. Radosavljević, S., Stojanović, J., Radosavljević-Mihajlović, A., Vuković, N., Matijašević, S., Stojanović, M. and Kašić, V., Ceramic clays from the western part of the Tamnava Tertiary Basin, Serbia: deposits and clay types 75-83, ANNALES GÉOLOGIQUES DE LA PÉNINSULE BALKANIQUE, 2014.

10. Gržetić, I. A., Jelenković, R. J., Prirodni radioaktivni elementi, geološko poreklo, oblici pojavljivanja i migracije, Jonizujuća zračenja iz prirode - monografija, ISBN 86-80055-75-1, 1995.

11. IAEA Technical Reports Series No.295 - Measurement of Radionuclides in Food and the Environment Section 5. - Collection and Preparation of Samples.

12. ISO 18589-1:2005 Measurement of radioactivity in the environment - Soil - General guidelines and definitions.

13. ISO 18589-2:2007 Measurement of radioactivity in the environment - Soil - Guidance for the selection of the sampling strategy, sampling and pre-treatment of samples.

14. ISO 18589-3:2007 Measurement of radioactivity in the environment - Soil - Measurement of gammaemitting radionuclides.

15. ORTEC Gamma Vision - 32 Gamma-Ray Spectrum Analysis and MCA Emulator for Microsoft Windows 95, 98, 2000, and NT A66-B32, Software User's Manual, U.S.A. 2002.

16. Pravilnik o granicama radioaktivne kontaminacije životne sredine i načinu sprovođenja dekontaminacije, Službeni list SRJ br. 9/99. 


\section{UTICAJ RADIONUKLIDA IZ ZEMLJIŠTA I GLINOVITOG MATERIJALA LEŽIŠTA „ZBEGOVI“ DONJE CRNILJEVO NA ŽIVOTNU SREDINU}

$U$ radu su prikazani rezultati ispitivanja sadržaja radionuklida u uzorcima zemljišta $i$ glinovitog materijala površinskog kopa „Zbegovi“ Donje Crniljevo. Rezultati ispitivanja pokazuju da aktivnost uzoraka iz glinovitog materijala $i$ okolnog zemljišta potiče uglavnom od prirodnih radionuklida: ${ }^{232} \mathrm{Th},{ }^{238} U{ }^{i}{ }^{40} \mathrm{~K}$. Radioaktivnost uzoraka je određena gama spektrometrijskom metodom uz korišćenje HPGe detektora relativne efikasnosti 56,2\%. Dobijeni rezultati pokazuju da ispitivani uzorci mogu da se koristiti kao materijal za opekarske i keramičke proivode, kozmetici i da ispitivano ležište gline ne ispoljva negativan uticaj na ljude, biljke i životinje.

Ključne reči: glina, zemljište, radioaktivnost, ${ }^{232} \mathrm{Th},{ }^{238} \mathrm{U},{ }^{40} \mathrm{~K}$. 